\title{
VOLATILITAS INDEKS KOMPOSIT PASAR MODAL ASEAN-3
}

\author{
Anhar Fauzan Priyono \\ Fakultas Ekonomi dan Bisnis \\ Universitas Padjadjaran \\ Email: fauzan.fe@unpad.ac.id
}

\begin{abstract}
Rapid integration between domestic and world economy in the last decade has been a major issue. For Indonesia, the situation has been accelerated by the adoption of floating exchange rate regime in 1997, also with the development of Indonesia stock exchange.

One notable financial variable that often exposed to external shocks is stock market index. This research will analyzed the behavior of 3 major stock market indices in ASEAN, those are Jakarta Composite Index (JCI), Kuala Lumpur stock index (KLSE), and Singapore stock index (STI). The employment of volatility model is chosen to figured the behavior of those 3 indices, and to analyze the aggregate investment in each stock market. Observation will be based upon monthly basis, from 2010 until 2015.

The findings in this research are (i) similarity in the movement behavior of ASEAN-3 stock market indices, (ii) Indonesia stock market shows the highest aggregate investment return relative to Malaysia and Singapore, (iii) Singapore stock market shows the lowest aggregate investment risk relative to Indonesia and Malaysia, as the representation of more developed stock market.
\end{abstract}

Keywords : ASEAN-3, integration, aggregate investment, volatility model

\section{PENDAHULUAN}

ntegrasi perekonomian Indonesia dengan dunia semakin | meningkat dalam dekade terakhir ini. Di lain pihak, sejak diterapkannya floating exchange rate regime di tahun 1997, perekonomian Indonesia akan makin rentan terhadap guncangan eksternal. Peningkatan kekuatan ekonomi Amerika Serikat akhir-akhir ini menjadi salah satu alasan melemahnya nilai tukar rupiah terhadap US Dollar, selain alasan kinerja perekonomian domestik.

Merujuk pada konsep makro ekonomi, dimana perdagangan internasional, dalam hal ini adalah aktivitas ekspor dan impor adalah fungsi dari nilai tukar, maka setiap penurunan (depresiasi), atau peningkatan (apresiasi) dari nilai tukar rupiah terhadap mata uang asing utama dunia, akan dapat

QE Journal |Vol.05 - No. 04 Desember 2016 - 178 
berdampak secara langsung pada volume perdagangan. Di lain pihak, selain volume perdagangan (neraca berjalan/current account), komponen lainnya dalam neraca pembayaran (balance of payment), yaitu neraca modal (capital account) dimana pembentukan modal dapat berasal dari mekanisme portofolio dan investasi langsung (direct investment). Keseluruhan dari neraca-neraca tersebut memang memiliki keterkaitan dengan nilai tukar yang menjadi salah satu indikator makro ekonomi utama dari suatu negara.

Sektor lain yang cukup memberikan kontribusi terhadap kinerja perekonomian Indonesia adalah pasar modal. Pasar modal diyakini dapat menjadi sarana permodalan jangka pendek yang dalam prakteknya akan mampu menjadi alternatif pada saat melemahnya kinerja perbankan sebagai intermediator keuangan. Bursa Efek Indonesia sendiri tergolong pasar modal yang masih berkembang, yang hingga saat ini, aktivitas perdagangannya masih lebih banyak dikuasai oleh investor asing relatif dari investor domestik. Kinerja Bursa Efek Indonesia (BEI), yaitu Indeks Harga Saham Gabungan (IHSG) seringkali dijadikan indikator makro ekonomi Indonesia. Peningkatan dalam kinerja BEI akan menjadi indikator meningkatnya kinerja agregat dari perusahaan-perusahaan yang terdaftar sebagai emiten.

Berikut adalah perkembangan pertumbuhan nilai tukar rupiah terhadap US Dollar, dan pertumbuhan IHSG Indonesia yang dipantau dalam frekuensi bulanan:.

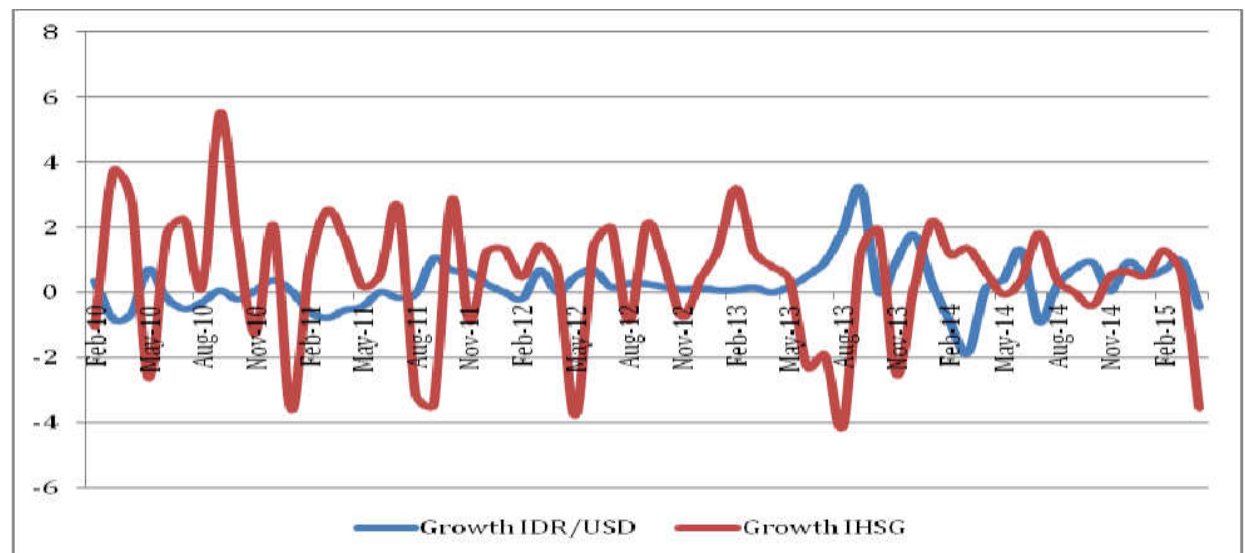

Gambar 1. Pertumbuhan Nilai Tukar Rupiah/US Dollar dan IHSG (\%) Februari 2010 - April 2015

QE Journal | Vol.05 - No. 04 Desember 2016 - 179 
Keterangan : Rata-rata pertumbuhan nilai tukar bulanan Rupiah/US Dollar adalah $0,23 \%$ dengan standar deviasi $0,74 \%$, sedangkan rata-rata pertumbuhan IHSG adalah 0,46\% dengan standar deviasi 1,96\%.

Dalam gambar (1) diatas, dapat dilihat bahwa volatilitas dari kedua indikator makro ekonomi tersebut cukup tinggi dan bervariasi, khususnya adalah volatilitas IHSG. Hal ini dapat dilihat dari cukup besarnya perbedaan antara nilai rata-rata kedua variabel tersebut dengan nilai standar deviasinya. Volatilitas atas kedua variabel tersebut tentunya akan menciptakan ketidaknyamanan dari dua aspek pengamatan ekonomi, yaitu dari sisi makro maupun mikro. Dalam sisi makro, volatilitas kedua variabel tersebut dapat menunjukkan country risk, sedangkan dari sisi mikro akan mempersulit pengambilan keputusan di area pengambilan kebijakan dan juga investor. Khusus dalam level perusahaan, utamanya yang tergolong Multi National Company (MNC), maka peramalan nilai tukar dan/atau indeks saham gabungan akan sangat berguna untuk upaya-upaya hedging, pembiayaan jangka pendek, keputusan investasi jangka pendek dan panjang, capital budgeting, serta perhitungan cash flow. Merujuk pada hal tersebut, maka nilai tukar dan juga indeks harga saham akan menjadi dua faktor yang dapat memengaruhi daya saing perusahaan-perusahaan tersebut.

Berikut adalah ilustrasi pergerakan pertumbuhan IHSG, KLSE (indeks Malaysia) dan STI (Indeks Singapura):.

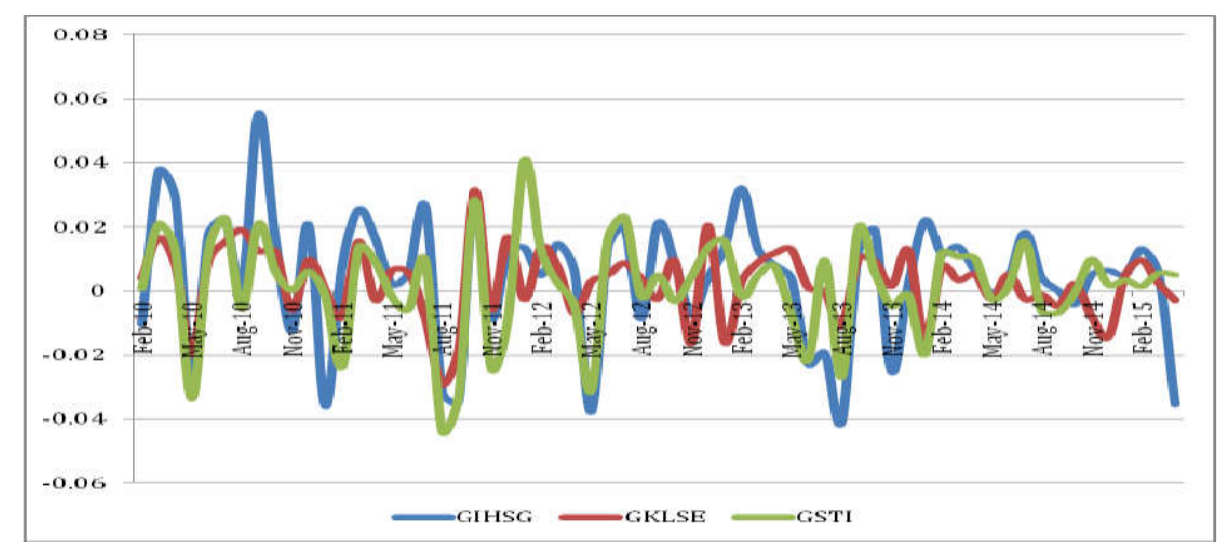

Sumber: Yahoo Finance (diolah)

Gambar 2. Pergerakan Pertumbuhan IHSG (GIHSG), KLSE (GKLSE), dan STI (GSTI) Februari 2010 - April 2015

QE Journal | Vol.05 - No. 04 Desember 2016 - 180 
Gambar 2 diatas menunjukkan bahwa secara ilustratif terlihat adanya kesamaan pergerakan pertumbuhan diantara tiga indeks komposit pasar modal di ASEAN, yaitu IHSG, KLSE, dan STI. Pertumbuhan IHSG memperlihatkan dinamika yang cukup besar dibandingkan dengan pertumbuhan KLSE dan STI. Hal ini setidaknya memberikan indikasi adanya korelasi yang kuat diantara ketiga indeks komposit tersebut, yang kemudian akan diuji untuk mengetahui tingkat integrasinya.

Terdapat dua pendekatan dalam konteks forecasting pada literatur, untuk indeks saham gabungan (komposit), yaitu pendekatan fundamental dan teknikal. Pendekatan fundamental memanfaatkan analisa hubungan antara variabel-variabel ekonomi dalam melakukan proses forecasting, sedangkan pendekatan teknikal memanfaatkan perilaku historis.

Pendekatan teknikal memanfaatkan pola dan karakteristik historis dalam indeks saham komposit untuk memprediksikan pergerakan indeks saham komposit di masa yang akan datang. Pada pendekatan ini, dipercaya bahwa data runtut waktu memiliki karakteristik siklus dan/atau musiman, yang memiliki perulangan, sehingga dimungkinkan melakukan prediksi berbasiskan nilai historisnya.

Akgiray (1989) menemukan adanya volatility clustering (ARCH effect) pada pertumbuhan indeks harga saham, Schwert (1990) menemukan karakter yang sama, namun pada pasar derivatif, yaitu futures market, sedangkan Engle dan Mustafa (1992) menyimpulkan bahwa pada pertumbuhan harga saham individual (individual stock return) juga ditemui fenomena volatility clustering.

\section{METODOLOGI PENELITIAN}

Teknik permodelan yang akan dimanfaatkan dalam kajian ini serta dapat menjadi salah satu upaya meramalkan pergerakan indeks saham komposit, sekaligus pergerakan volatilitasnya adalah model volatilitas, yaitu Generalized Autoregressive Conditional Heteroskedasticity (GARCH) dan beberapa variannya. Teknik permodelan GARCH ini dianggap mampu menjelaskan fenomena volatility clustering, fat tail dan leptokurtosis yang terdapat pada data-data finansial seperti nilai tukar dan indeks harga saham gabungan. 
Perhitungan pertumbuhan nilai tukar dan indeks harga saham gabungan adalah mengikuti formula berikut:.

$$
G J C I_{t}=\log \left(\frac{J C I_{t}}{J C I_{t-1}}\right)
$$

dimana: $\mathrm{GJCI}=$ pertumbuhan indeks harga saham gabungan (Jakarta Composite Index).

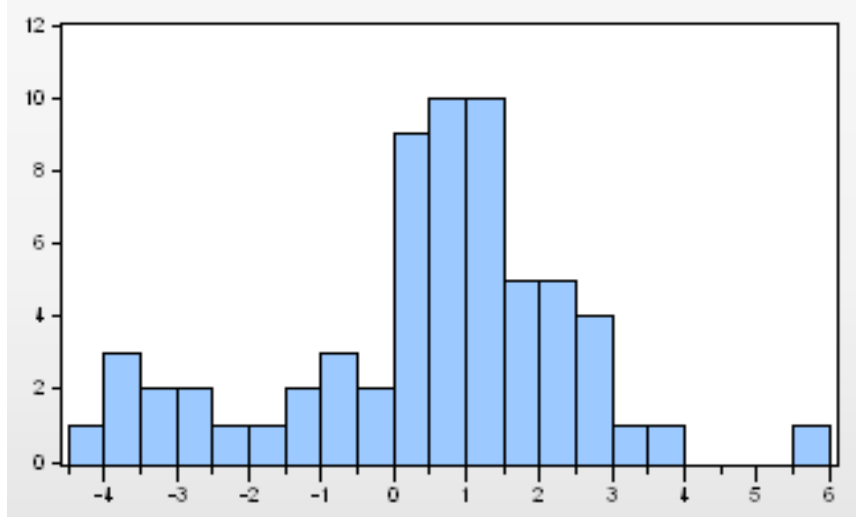

\begin{tabular}{lr}
\hline Series: GJCI \\
Sample 2010M02 2015 M04 \\
Obsenuations 63 \\
Mean & 0.459744 \\
Median & 0.645028 \\
Maximum & 5.541360 \\
Minimum & -4.099544 \\
Std. Dev. & 1.959011 \\
Skewness & -0.513789 \\
Kurtosis & 3.306924 \\
& \\
Jarque-Bera & 3.019059 \\
Probability & 0.221014 \\
\hline
\end{tabular}

Gambar 3. Statistik Deskriptif Pertumbuhan Indeks Harga Saham Gabungan

Menurut Gambar (3), dapat diketahui bahwa terdapat indikasi volatility clustering dan non-linearity pada pergerakan historis dari pertumbuhan indeks harga saham gabungan. Hal ini dapat diketahui setidaknya melalui informasi nilai kurtosis yang melebih batas normal (nilai kurtosis normal adalah maksimum 3), dan besaran standar deviasi untuk variabel tersebut yang jauh melebihi nilai rata-ratanya.

Pendekatan-pendekatan permodelan dalam basis model volatilitas yang akan dimanfaatkan dan kemudian dibandingkan kekuatan prediksinya dalam kajian ini adalah:

(1) GARCH(p,q) model ; dan (2) GARCH in Mean (GARCH-M) model Bollerslev (1986) dan Taylor (1986) mengemukakan bahwa GARCH memiliki kemampuan untuk mengakomodir nilai conditional variance untuk dipengaruhi oleh nilai sebelumnya. Persamaan umum untuk model $\operatorname{GARCH}(\mathrm{p}, \mathrm{q})$ dengan ordo $\mathrm{p}=1$, dan $\mathrm{q}=1$, adalah sebagai berikut:

$$
y_{t}=\mu+\phi y_{t-1}+u_{t}, \quad u_{t} \sim N\left(0, \sigma_{t}^{2}\right)
$$

QE Journal | Vol.05 - No. 04 Desember 2016 - 182 


$$
\sigma_{t}^{2}=\alpha_{0}+\alpha_{1} u_{t-1}^{2}+\beta \sigma_{t-1}^{2}
$$

Proses estimasi kedua persamaan diatas, dimana persamaan (2) adalah persamaan conditional mean yang dapat dimanfaatkan untuk memprediksikan pergerakan suatu variabel (pertumbuhan nilai tukar dan juga pertumbuhan indeks harga saham gabungan), dan persamaan (3) yang merupan persamaan conditional variance, untuk memprediksikan pergerakan volatilitasnya, kemudian berlanjut pada spesifikasi loglikelihood function (LLF) sebagai berikut:

$$
L=-\frac{T}{2} \log (2 \pi)-\frac{1}{2} \sum_{t=1}^{T} \log \left(\sigma_{t}^{2}\right)-\frac{1}{2} \sum_{t=1}^{T}\left(y_{t}-\mu-\phi y_{t-1}\right)^{2} / \sigma_{t}^{2}
$$

GARCH in Mean (GARCH-M), sesuai dengan penjelasan Engle, Lilien dan Robins (1987) dalam Brooks (2002: 480), dapat dimanfaatkan untuk melihat hubungan antara resiko investasi dengan pergerakan pertumbuhan (return) dari investasi tersebut. Implementasinya adalah conditional variance (resiko) atas pertumbuhan asset akan dimasukkan ke dalam persamaan conditional mean dengan bentuk sebagai berikut:

$$
y_{t}=\mu+\delta \sigma_{t}+u_{t}, u_{t} \sim N\left(0, \sigma_{t}^{2}\right)
$$

Dalam persamaan (5) tersebut bila koefisien $\delta$ bernilai positif dan signifikan, maka dapat disimpulkan setiap peningkatan resiko investasi yang diwakili oleh meningkatnya conditional variance akan berdampak pada peningkatan dalam mean return.

Pengujian keberadaan volatility clustering atas variabel nilai tukar dan indeks harga saham gabungan akan memanfaatkan $\mathrm{ARCH}$ effect test. Tahapan pengujian ARCH effect yang dijelaskan Brooks (2008) dalam Priyono dan Bustaman (2014) adalah sebagai berikut:

1. Melakukan estimasi regresi linier seperti tampak dalam persamaan berikut:

$$
y_{t}=\alpha_{0}+\alpha_{1} y_{t-1}+\alpha_{2} y_{t-2}+\ldots+\alpha_{n} y_{t-n}+e_{t}
$$

dimana:

$$
y_{t}=I H S G=\quad y_{t-1}=\text { tingkat kelambanan }
$$

2. Residual yang didapat akan dimanfaatkan dalam persamaan berikut: 


$$
\hat{e}_{t}^{2}=\gamma_{0}+\gamma_{1} \hat{e}_{t-1}^{2}+\gamma_{2} \hat{e}_{t-2}^{2}+\cdots+\gamma_{q} \hat{e}_{t-q}^{2}+v_{t}
$$

dimana $\boldsymbol{v}_{\boldsymbol{t}}$ bersifat iid

3. Menghitung uji statistik yang didefinisikan sebagai $\boldsymbol{T R}^{\mathbf{2}}$ (jumlah observasi dikalikan dengan koefisien determinasi dari persamaan pada tahap 2), mengikuti distribusi $\chi^{\mathbf{2}}(\boldsymbol{q})$.

4. Hipotesis-hipotesis berkaitan pengujian statistik pada tahap 3 adalah sebagai berikut:

$$
\begin{aligned}
& H_{0}: \gamma_{1}=0 \text { dan } \gamma_{2}=0 \text { dan } \ldots \text { dan } \gamma_{q}=0 \ldots \\
& H_{1}: \gamma_{1} \neq 0 \text { atau } \gamma_{2} \neq 0 \text { atau } \ldots \text { atau } \gamma_{q} \neq 0
\end{aligned}
$$

Bila nilai uji statistik lebih besar daripada nilai kritis pada distribusi $\chi^{2}$, maka hipotesis nol ditolak.

Selanjutnya, perbandingan kinerja peramalan dari kedua teknik permodelan tersebut akan dilakukan menurut beberapa informasi sebagai berikut:

(1) Root Mean Squared Error (RMSE); (2) Mean Absolute Deviation (MAD);

(3) Mean Absolute Percentage Error (MAPE); (4) Akaike Information Criterion (AIC); (5) Schwarz Criterion (SC); (6) Hannan-Quinn-Bayesian Criterion (HQBC)

\section{HASIL DAN PEMBAHASAN}

Volatilitas pasar keuangan di negara-negara ASEAN-3 diukur dinamika pertumbuhan indeks harga saham komposit atas masing-masing negara yang sedang diamati. Pendekatan yang digunakan untuk mempelajari volatilitas pasar keuangan tersebut adalah model volatilitas dengan varian GARCH(1,1) dan GARCH-M secara khusus untuk melihat mekanisme risk and return dalam tiap pasar modal tersebut secara agregat. Negara-negara yang diamati adalah Indonesia (GIHSG), Malaysia (GKLSE), dan Singapura (GSTI).

Berikut adalah ilustrasi dari pergerakan pertumbuhan indeks harga komposit pasar modal-pasar modal tersebut diatas yang dipantau dalam frekuensi bulanan: 


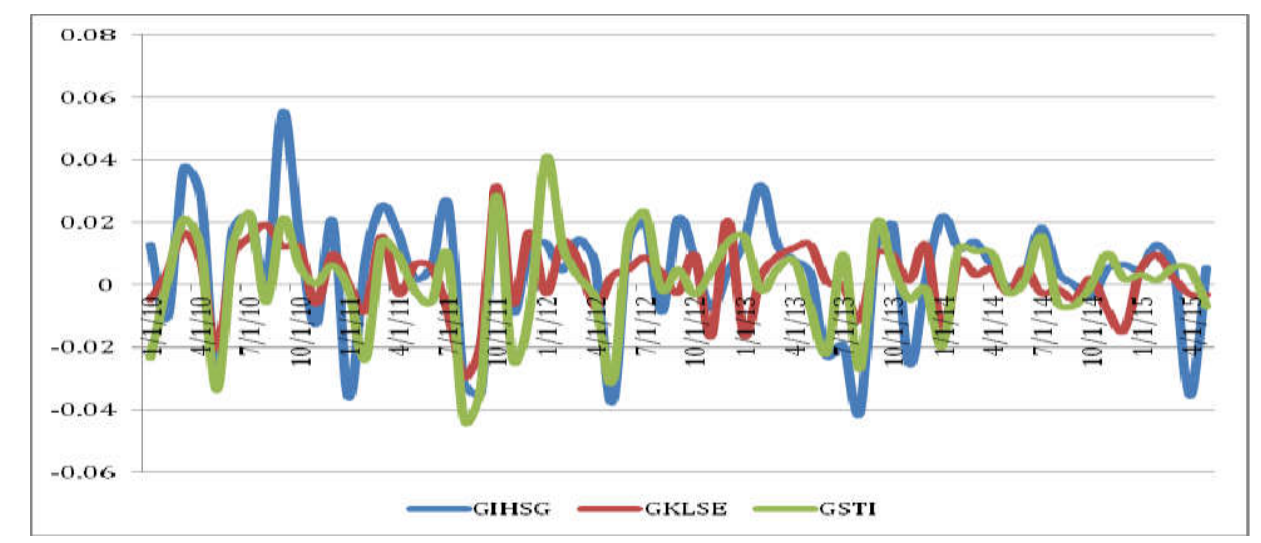

Sumber: Perhitungan Penulis

Gambar 4. Pertumbuhan Indeks Harga Komposit Pasar Modal ASEAN3 (Januari 2010 - Mei 2015)

Berdasarkan Gambar.4 tersebut diatas dapat dibuat kesimpulan awal bahwa volatilitas pertumbuhan IHSG (GIHSG) adalah yang paling tinggi dibandingkan pertumbuhan indeks KLSE (GKLSE) dan pertumbuhan indeks Singapura (GSTI). GKLSE memperlihatkan volatilitas yang paling rendah diantara kedua kinerja volatilitas pasar modal lainnya. Dalam periode sekitar Oktober 2011 hingga awal 2012, volatilitas GSTI sedikit lebih tinggi, bahkan jika dibandingkan dengan GIHSG.

Hasil permodelan perilaku pertumbuhan indeks pasar modal negaranegara di ASEAN-3 adalah sebagai berikut:

1. Pasar Modal Indonesia (GIHSG):

Persamaan conditional mean untuk melihat perilaku pergerakan pertumbuhan IHSG adalah sebagai berikut (z-statistik dalam kurung):

$$
\text { GIHSG }_{\boldsymbol{t}}=0.006 \text { 4-0.211GIHSG }
$$

$$
(15.39)^{* * *}(-1.68)^{*}
$$

keterangan: ${ }^{* * *}, * *$, dan $*$ berturut-turut adalah signifikan pada level 1\%, 5\%, dan $10 \%$

Persamaan conditional variance untuk melihat perilaku volatilitas pertumbuhan IHSG adalah sebagai berikut (z-statistik dalam kurung):

$$
\begin{array}{r}
\left(\sigma_{e}^{2}\right)_{t}=5.86 * 10^{-6}-0.127 e^{2}{ }_{t-1}+1.09 \sigma_{e_{t-1}^{2}} \\
(1.03)(-2.31)^{* *}(18.66)^{* * *}
\end{array}
$$

QE Journal | Vol.05 - No. 04 Desember 2016 - 185 
keterangan: ${ }^{* * * * *}$, dan ${ }^{*}$ berturut-turut adalah signifikan pada level $1 \%, 5 \%$, dan $10 \%$

Sedangkan ilustrasi pergerakan volatilitas GIHSG yang memperlihatkan proksi resiko investasi agregat di pasar modal Indonesia adalah sebagai berikut:

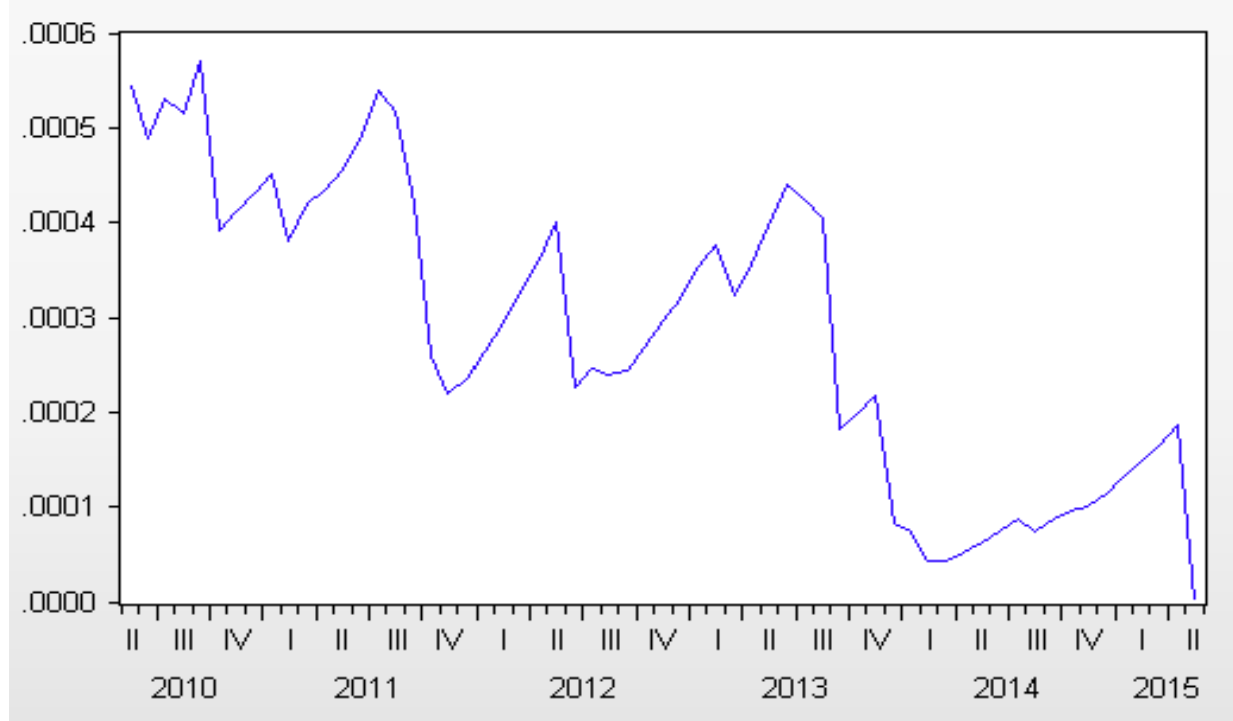

Sumber: Perhitungan Penulis

\section{Gambar 5. Volatilitas GIHSG}

Dalam Gambar.5 dapat diketahui bahwa risiko investasi agregat di pasar modal Indonesia memperlihatkan kecenderungan menurun, walaupun terdapat fluktuasi di tiap tahun dengan pola yang cenderung sama. Pola yang dimaksud adalah meningkatnya risiko investasi di tiap kuartal ke-2 di tiap tahun, dan menurun di kuartal berikutnya.

2. Pasar Modal Malaysia (GKLSE):

Persamaan conditional mean untuk melihat perilaku pergerakan pertumbuhan KLSE adalah sebagai berikut (z-statistik dalam kurung):

$$
G K L S E_{t}=0.003-0.269 G K L S_{t} E_{13}
$$

$$
(1.94)^{*} \quad(-2.94)^{* * *}
$$

keterangan: ${ }^{* * * *},{ }^{*}$, dan ${ }^{*}$ berturut-turut adalah signifikan pada level $1 \%, 5 \%$, dan $10 \%$ 
Persamaan conditional variance untuk melihat perilaku volatilitas pertumbuhan KLSE adalah sebagai berikut (z-statistik dalam kurung):

$$
\left(\sigma_{u}^{2}\right)_{t}=4.24 * 10^{-5}+0.459 u^{2}{ }_{t-1}+0.149 \sigma_{u_{t-1}}^{2}
$$

keterangan: ${ }^{* * *}, * *$, dan ${ }^{*}$ berturut-turut adalah signifikan pada level $1 \%, 5 \%$, dan $10 \%$

Sedangkan ilustrasi pergerakan volatilitas GKLSE yang memperlihatkan proksi resiko investasi agregat di pasar modal Malaysia adalah sebagai berikut:

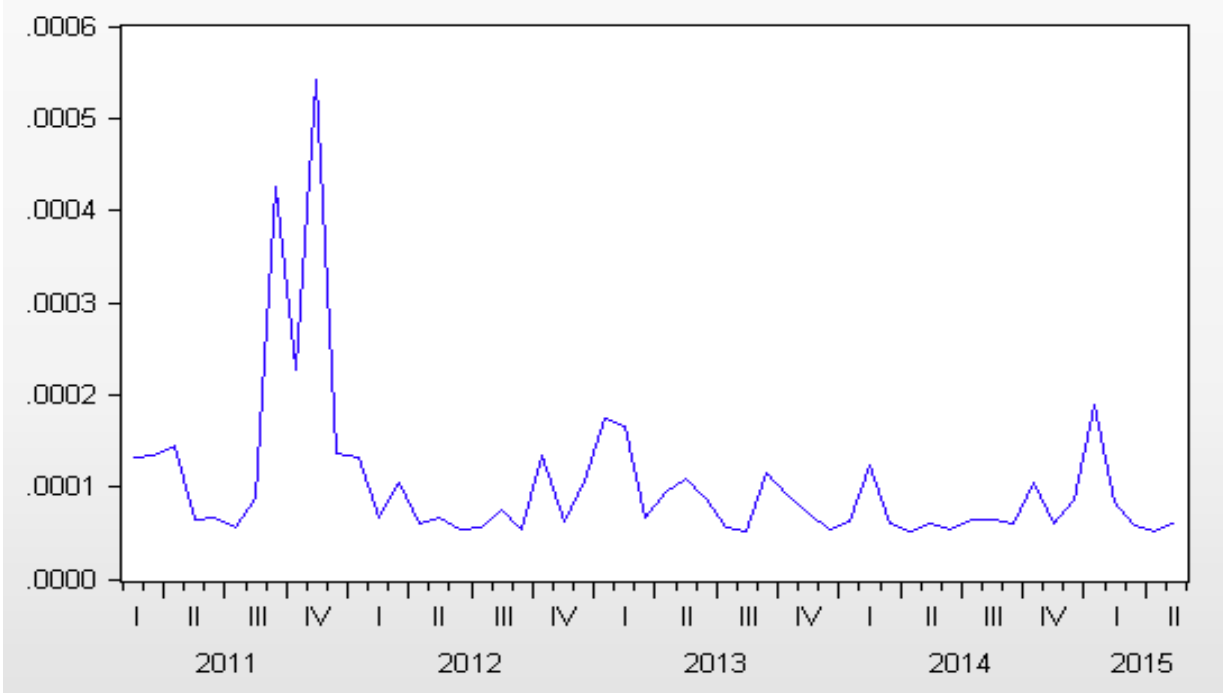

Sumber: Perhitungan Penulis

\section{Gambar 6. Volatilitas GKLSE}

Dalam Gambar.6 dapat diketahui bahwa risiko investasi agregat di pasar modal Malaysia cenderung stabil dan rendah selama periode observasi, terkecuali pada kuartal ke-3 dan ke-4 di tahun 2011.

3. Pasar Modal Singapura (GSTI):

Persamaan conditional mean untuk melihat perilaku pergerakan pertumbuhan STI adalah sebagai berikut (z-statistik dalam kurung):

$$
\text { GSTI }_{t}=0.0008-0.228 \text { GST }_{-4}
$$


keterangan: ${ }^{* * * * *}$, dan ${ }^{*}$ berturut-turut adalah signifikan pada level $1 \%, 5 \%$, dan $10 \%$

Persamaan conditional variance untuk melihat perilaku volatilitas pertumbuhan STI adalah sebagai berikut (z-statistik dalam kurung):

$$
\left(\sigma_{z}^{2}\right)_{t}=-1.87 * 10^{-5}+0.007 z^{2}{ }_{t-1}+1.05 \sigma_{z}^{2}{ }_{t-1}
$$

$$
(-0.66)
$$

keterangan: $* * *, * *$, dan * berturut-turut adalah signifikan pada level $1 \%, 5 \%$, dan $10 \%$

Sedangkan ilustrasi pergerakan volatilitas GSTI yang memperlihatkan proksi resiko investasi agregat di pasar modal Singapura adalah sebagai berikut:

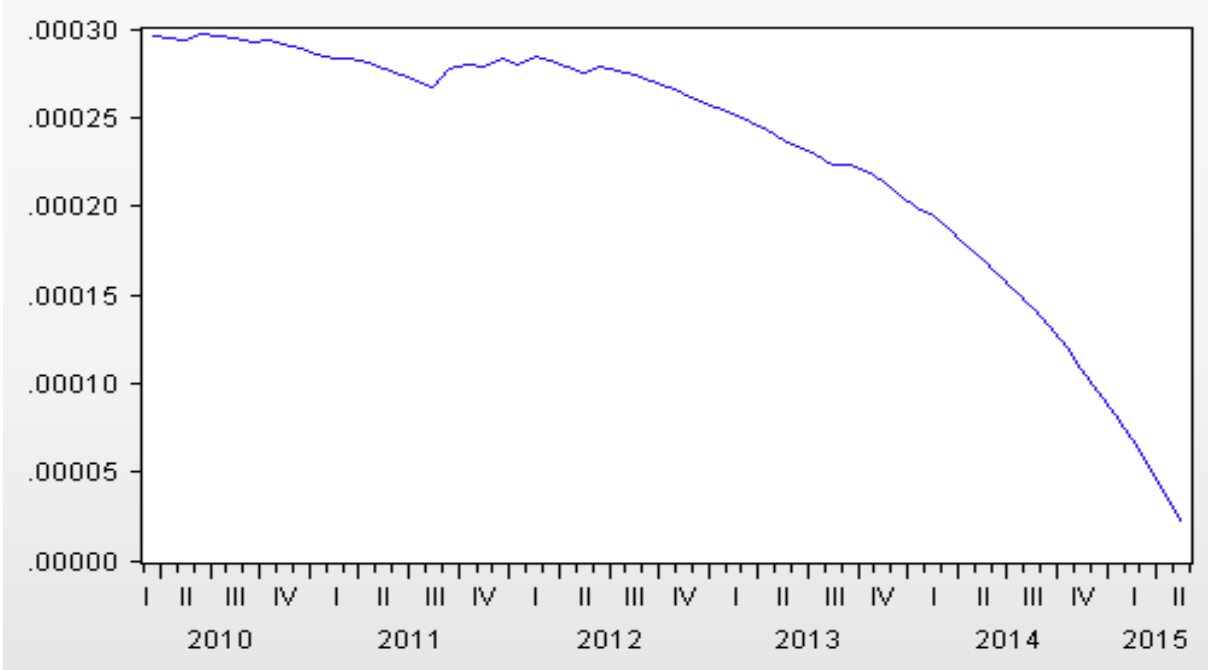

Sumber: Perhitungan Penulis

Gambar 7. Volatilitas GSTI

Dalam Gambar.7 dapat diketahui bahwa risiko investasi agregat pada pasar modal di Singapura menunjukkan trend yang menurun cukup tajam selama periode observasi.

\section{KESIMPULAN}

Arah pergerakan atau perilaku indeks saham gabungan (komposit) di ASEAN-3, yaitu di Indonesia, Malaysia, dan Singapura menunjukkan karakter yang sama. Hal ini lebih dikarenakan adanya integrasi keuangan 
yang tinggi diantara pasar modal regional, maupun reaksi dari dinamika perekonomian global di antara negara-negara tersebut.

Secara umum dapat disimpulkan bahwa pada periode tahun 2010 - 2015 (dipantau pada frekuensi bulanan), pasar modal Indonesia menunjukkan rata-rata pertumbuhan indeks bulanan yang tertinggi dibandingkan dengan Malaysia dan Singapura. Di lain pihak didapatkan informasi bahwa resiko investasi agregat di pasar modal Indonesia menunjukkan kecenderungan menurun, sementara pasar modal Malaysia cenderung stabil. Pasar modal Singapura menunjukkan trend resiko investasi agregat yang juga menurun, namun tingkatannya lebih rendah daripada pasar modal Indonesia dan Malaysia. Temuan dari penelitian ini dapat dijadikan salah satu gambaran bahwa Singapura sebagai negara yang memiliki pasar modal yang telah maju, menunjukkan kinerja yang lebih baik. Hal ini dapat dilihat dari tingkat resiko investasi agregatnya yang lebih rendah. Pasar modal Indonesia yang masih berkembang, dapat diarahkan menuju pasar modal yang lebih baik. Hal ini dapat diwujudkan dengan mengoptimalkan peran Otoritas Jasa Keuangan, khususnya dalam pengawasan pasar modal, untuk menjamin terciptanya perdagangan efek yang efisien. Efisiensi perdagangan efek dapat tercapai pada saat seluruh dana dapat teralokasikan pada saham-saham dimana emitten-nya memiliki future discounted cashflow yang baik.

\section{DAFTAR PUSTAKA}

Adam, K., T. Jappelli, A. Menichini, M. Padula, and M. Pagana. 2002. "Analyze, Compare, and Apply Alternative Indicators and Monitoring Methodologies to Measure the Evolution of Capital Market Integration in the European Union". Center for Studies in Economics and Finance. University of Salerno.

Akgiray, V. 1989. "Conditional Heteroskedasticity in Time Series of Stock Returns: Evidence and Forecasts". Journal of Business, vol. 62, 55 80 .

Bollerslev, T. 1986. "Generalized Autoregressive Conditional Heteroskedasticity". Journal of Econometrics 3: 307 - 327.

Brooks, Chris. 2002. Introductory Econometrics for Finance. Cambridge University Press.

QE Journal | Vol.05 - No. 04 Desember 2016 - 189 
Cassel G. (1923), Money and Foreign Exchange. Macmillan, New York

Dornbusch R. (1973), “Currency Depreciation, Hoarding and relative Prices". Journal of political Economy, pp. 893-915.

Dornbusch R. (1979), "Monetary policy under Exchange Rate Flexibility", in Managed Exchange Rate Flexibility: The Recent Experience. Federal Reserve Bank of Boston, Conference Series Volume 20, pp. 90-122.

Engle, R., D. Lilien \& R. Robins. 1987. "Estimating Time-Varying Risk Premia in the Term Structure: The ARCH-M Model". Econometrica 55: 391 - 407.

Fama E. F. (1965), "The Behavior of Stock Market Prices". Journal of Business, n. 38, pp. 34-105.

Mandelbrot B. B. (1963), "The variation of certain speculative prices". Journal of Business, n. 36, pp. 394-419.

Meese R., Rogoff K. (1983), “Empirical Exchange Rate Models of the Seventies: How well do they fit out of sample?". Journal of International Economics, pp. 3-24.

Mundell R. (1968), International Economics, MacMillan, New York.

Park, Cyn-Young. 2013. "Asian Capital Market Integration: Theory and Evidence". ADB Economics Working Paper Series No. 351, June 2013.

Priyono, A.F., and Bustaman, A. 2013. "Volatility Transmission between Exchange Rates and Stock Prices in Indonesia: Post 1997 Asia Crisis". Working Paper in Economics and Development Studies (WoPEDS) 201404, Department of Economics, Padjadjaran University.

Samuelson P.(1964), "Theoretical Notes on Trade Problems", in Review of Economics and Statistics, pp. 145-154.

Schwert, G. William. 1989. "Why Does Stock Market Volatility Change Over Time". Journal of Finance, 45, 1115 - 1153.

Taylor, S. 1986. Modeling Financial Time Series. John Wiley \& Sons.. 